Dr. Poljanšek S., Dr. Vilhar U., Dr. Levanič T. ${ }^{1}$

\title{
GREEN WATER RECONSTRUCTED FOR RIŽANA WATERSHED, SW SLOVENIA
}

\author{
Slovenian Forestry Institute, Večna pot 2, 1000 Ljubljana, Slovenia \\ ${ }^{1}$ Corresponding author: tom.levanic@gozdis.si
}

\begin{abstract}
In this case study, set in southwest Slovenia, the feasibility of reconstructing green water (the combined amount of evaporated and transpired water in trees and available in the soil), was investigated. In a simplified scheme, the amounts of green water were calculated as the difference between precipitation and discharge of the Rižana river. Based on the methods of dendroclimatology, the climate signal was tested on black pine (Pinus nigra Arnold) trees growing in the southwestern part of the Rižana watershed near the Slovenian sea coast. Results showed that the measured tree-ring parameters of tree-ring width and density are strongly dependent on the amount of green water. The strongest correlation was between available green water in the period May-August and tree-ring width $(r=0.61)$ and latewood width $(r=0.64)$ (both $n=46, p<0.001)$. The climate signal is significant and stable through time, which enabled the reconstruction of green water data into the period before instrumentally measured data. Green water data from the May-August period were extended from 1966 back to 1937 using tree-ring width, and back to 1940 using latewood width. With additional coring of older trees and the extension of existing chronologies, even longer reconstructions could be developed.
\end{abstract}

\section{KEY WORDS}

Green water, tree-ring width, tree-ring density, dendrochronology, dendroclimatology, reconstruction

\section{INTRODUCTION}

Forests have an important influence on the water cycle. They regulate surface and groundwater flow, protect soil from erosion, and replenish and cleanse the water supply (Chang 2006; Ernst et al. 2004). For these reasons, forests are an essential part of water supply areas and should be considered as protective forests with increased water functions, or even have legal status as protected areas (Muys et al. 2011). The role of forests on the quality of water sources is therefore unquestionable, however, depending on factors like tree species and forest composition, season, topography and soil, forests also use water (Dawson 1996). Canopies intercept precipitation, trees evaporate and transpire water from their foliage, use water to function and to cool tree crowns in summer heat, and above all, to grow (Oishi et al. 2010). The more water trees use, the less will be available to others. While in areas with abundant precipitation dense forest stands present no competition to humans, this relationship can be different in water-limited areas and is already a focal point for several research projects ((Nisbet 2005) and the references therein).

In a simplified scheme, the quantity of available water in a forest, the so-called green water (Falkenmark and Rockström 2006), depends on the amount of precipitation, soil moisture and water in the form of evapotranspiration (ET, the sum of evaporation and plant transpiration). In this paper, values of soil moisture and ET were combined and categorised as green water (GW), in order to reflect the amount of water that is most strongly connected to tree growth. Forests dynamically adapt to GW and climatic factors through time on various levels: tree growth, stand density, the percentage of the forest cover, the variability of tree species, etc. In light of recent and forecasted climate change, changes in forest structure should be considered in forest hydrology management, especially in areas, where water quantity needs to meet increasing water use by people, agriculture, industry and tourism on one side and decreased precipitation on the other. This is the case 
in the Mediterranean region, where water is already recognized as a key factor, connecting natural sources, environmental concerns and societal needs (Gaelle and Mohammed 2011). While there are plans to cut water use in industry and among people, it is also important to investigate the role of forestry, and how forests from a particular watershed react to an amount of water.

One such area is the Rižana river watershed, a supply area for the coastal part of SW Slovenia, in the central northern part of the Mediterranean. The watershed and its karst aquifer are recharged directly from precipitation and indirectly from ephemeral surface streams (Janža 2010). Ground water from this catchment drains towards the Gulf of Trieste and the Kvarner Gulf, and also towards the southwest, where it emerges at the Rižana spring or recharges aquifer layers below the flysch cover (Janža 2010). As a result of climate change, the Rižana river already shows a negative trend in its annual mean daily discharge (Jurko 2009) and in the summer season, at the peak of forest growth, drinking water shortages already occur (personal communication). The area is partly covered by forest, mainly black pine (Pinus nigra Arnold) which has previously been shown to be a climate-sensitive species (Poljanšek and Levanič 2012), oaks (Quercus sp.) and other broadleaf species, whilst the rest is covered with a forest of pioneer species, grassland or agricultural land. In the past, the karst area was deforested, but it was reforestation after the 1850 s that led to black pine being the main species planted for re-establishing forest cover (Kranjc 2009). How forest cover dynamics and tree growth have influenced water availability in this area have not yet been studied. As such, water cycle-tree growth investigations are limited to the period of available climatic and hydrological data. Nonetheless, they can be reconstructed back in time by reconstructing the climatic signal embedded in tree-rings of trees from the area (Fritts 1976). Climate reconstruction, a part of dendroclimatology, has already been used to reconstruct streamflow or droughts from areas without long sets of recorded climate data (Saito et al. 2015; Spraggs et al. 2015).

In the light of the expected air temperature rise and decrease in precipitation in the region, and with consideration of $P$. nigra as currently the main species of the watershed in question, it is therefore important to investigate:

- If $P$. nigra trees contain GW signal,

- is the response to GW stable through time and

- if reconstruction of GW values is possible.

\section{MATERIALS AND METHODS}

\section{Study area description}

The investigated area is characterized by its deficit in humidity, owing to the prevailing karst features of the surface, high air temperatures and frequent droughts in the summer months, causing higher potential evapotranspiration than precipitation in July and August (Ogrin 2005). Climate is moderate continental to SubMediterranean, with an annual mean temperature of $9^{\circ} \mathrm{C}$ and precipitation between 1,300 in the western part and 1,700 mm year ${ }^{-1}$ in the southern (Janža 2010). The hottest months of the year are July and August and the coldest January and February. Precipitation regime in the studied area is complex due to transition zone character between continental and Mediterranean climate and topography which presents orographic barrier for the precipitation coming from the southwest. Precipitation pattern in the study area corresponds to this transitional character - majority of precipitation falls in autumn. July is the month with the smallest amount of precipitation in growing season $(98.6 \mathrm{~mm}$ ) and also the warmest. Absolutely driest month is February with 86.3 $\mathrm{mm}$. Despite of relatively large amount of precipitation during the growing season are upper layers of soil very dry in the growing season and vegetation exposed to drought stress due to high air temperatures and quick drain of the precipitation into the karst channel network.

The precipitation and temperature data used in this research were available from the Kozina weather station (http://meteo.arso.gov.si/). Weather station is located in the western part of the Rižana watershed (Error! Reference source not found.) at elevation $484 \mathrm{~m}$ a.s.l, which is approximately the average elevation of the studied area. Kozina meteorological station is the only station in the region with a continuous record from 1961 
till present. Other few meteorological stations in the study area have a shorter dataset, contain too many errors or gaps, or were in operation only very short period of time and thus useless for our study.

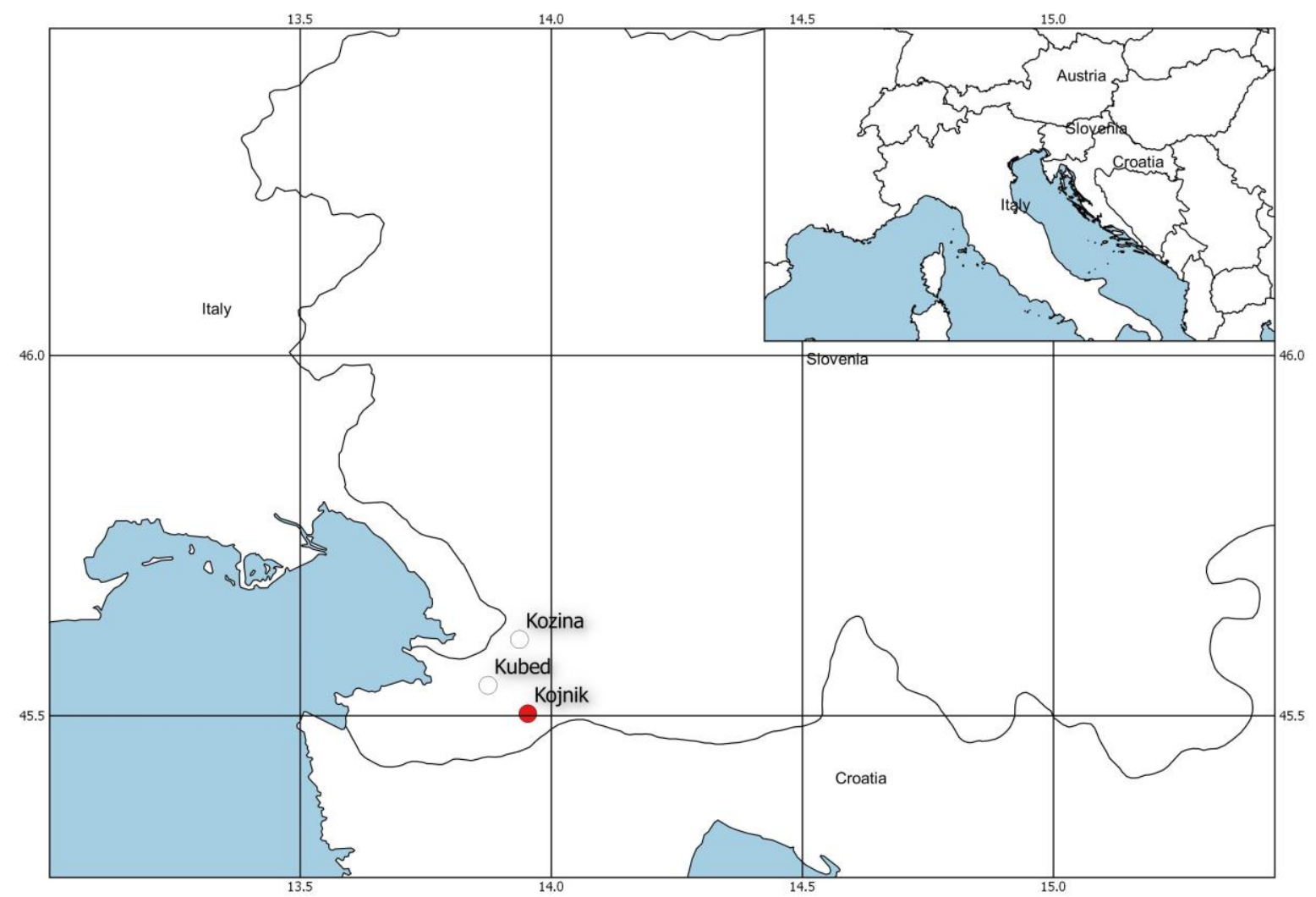

Figure 1: Sampling site, marked on the map with red dot, and white dots representing the Kozina weather and the Kubed river station.

The terrain of the catchment area is hilly and its altitude varies between $68 \mathrm{~m}$ above sea level at the Rižana spring and 1,028 $\mathrm{m}$ above sea level in the central part (Janža 2010). The difference in terrain and winds from the east (inland), the southeast (the Kvarner Gulf), and the west (the Gulf of Koper), form a very complex precipitation distribution for every storm event (Janža 2010). The Rižana river catchment covers an area of $204.66 \mathrm{~km}^{2}$, with the water protection zone covering $244 \mathrm{~km}^{2}$. In this study, we considered the entire water catchment of the Rižana river delineated by the surface water divide in the flysch area and by the tracing experiment in the area consisting of carbonate rocks (Krivic et al. 1987). For the time period 1965-2010 data on monthly average discharge of the Rižana river are available from the Kubed II station. This hydrological station is located in the vicinity of the river spring, approx. $8 \mathrm{~km}$ away from the weather station, at $58 \mathrm{~m}$ a.s.l. and 13 $\mathrm{km}$ from the Adriatic coast. Measured mean daily discharge is $3.31 \mathrm{~m}^{3} \mathrm{~s}^{-1}$, but is characterized by high variability in the average daily values throughout the year, ranging from $0.03 \mathrm{~m}^{3} \mathrm{~s}^{-1}$ up to $62.80 \mathrm{~m}^{3} \mathrm{~s}^{-1}$ (Janža 2010). Some water flow is not accounted for in the measurements: in times of abundant precipitation and saturated soil, the underground system overflows and the excess water runs through other underground caves and springs not measured by the Kubed II station. These events are mainly connected to autumn, winter and spring showery events outside the growing season, and for this reason their influence in this study was neglected. Also, not accounted for was the amount of drinking water extracted between the river spring and the river monitoring station, for two reasons. Firstly, the annual average water outtake is $0.1 \mathrm{~m}^{3} \mathrm{~s}^{-1}$ (personal communication) and is more or less constant throughout the year, and secondly, this represents only $3 \%$ of the river flow. For these reasons, the river flow data were not corrected for water loss.

\section{Available water calculation}


Based on the catchment water balance method, the potential amount of GW as the difference between precipitation and the Rižana river streamflow was calculated. The calculation was based on a simplified understanding of the water cycle. After every precipitation event, part of the water is stored in the system as soil moisture, while the remaining part of the precipitation runs off or percolates into the underground karst waters and from there to the Rižana spring. The calculated amount of GW is therefore presented as the water either stored within the basin inside vegetation, or already used for photosynthesis and growth. Higher GW rates are the result of a higher amount of precipitation, enabling greater tree growth; lower GW rates represent a lack of water, soil moisture stress and tree growth restrictions.

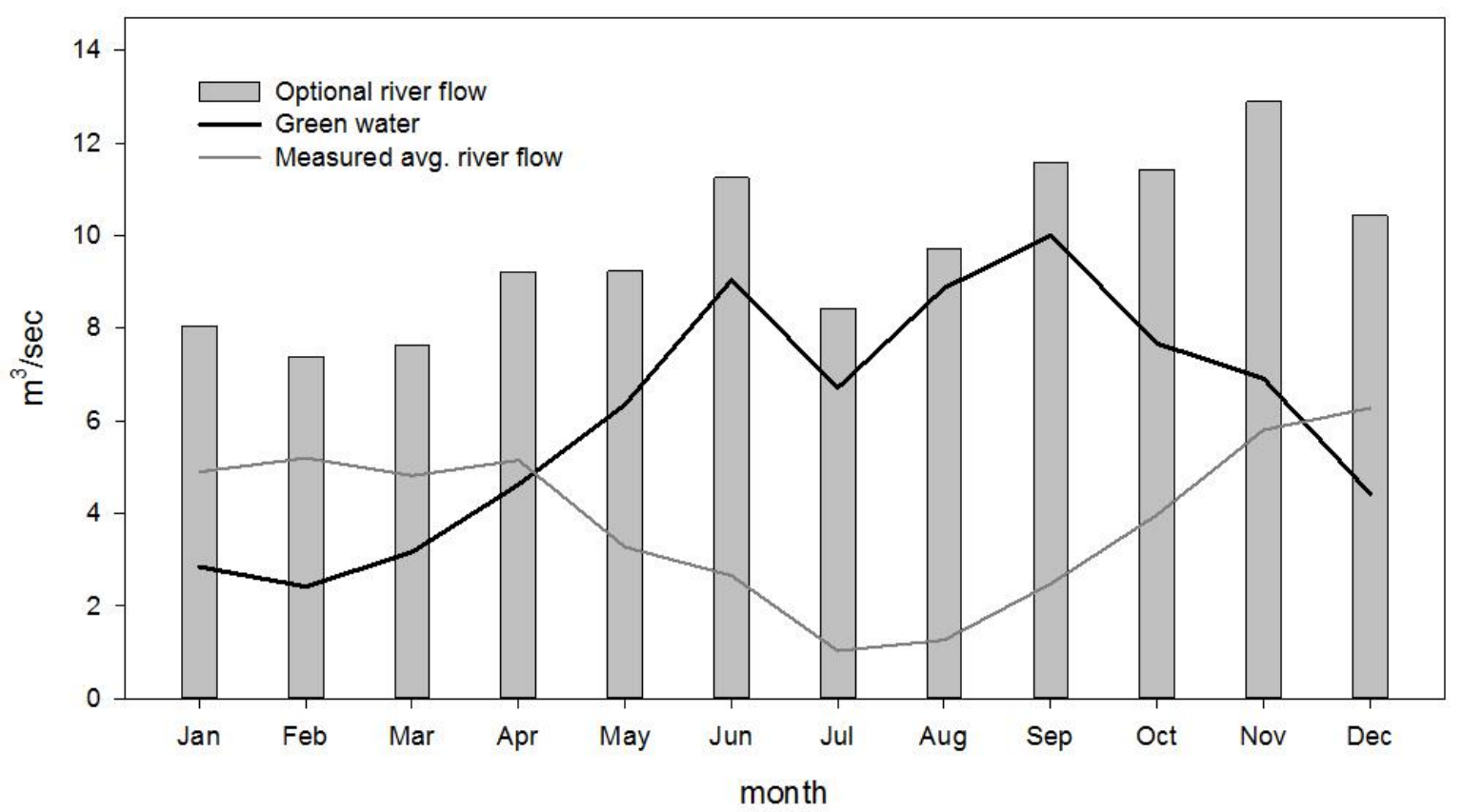

Figure 2: Data on optional river flow, calculated out of average monthly precipitation (grey columns), measured average river flow (grey line) and calculated difference as available water (black line).

Using monthly precipitation data, along with surface and streamflow from this catchment area, GW was calculated as follows: first, the original, measured monthly precipitation data in $\mathrm{mm}$ or $\mathrm{ml} / \mathrm{m}^{2}$, were converted to $\mathrm{m}^{3} / \mathrm{m}^{2}$ using data on the catchment area surface. Next, the precipitation rate was multiplied by the surface area of the catchment, giving the total monthly amount of precipitation in $\mathrm{m}^{3}$. This monthly amount of precipitation from the catchment was then divided by the number of seconds in an average month. This way the maximum possible discharge in $\mathrm{m}^{3} / \mathrm{s}$ was calculated, as if there was no water use in the area, the same as for the measured river discharge. Out of many available river flow data, the mean monthly values of river flow turned out to be the most appropriate for our study. Finally, the difference between the maximum possible discharge and the mean values of river flow was calculated (Error! Reference source not found.). The catchment water balance method defines GW as the amount of water retained in the ecosystem, which is calculated as the measured discharge subtracted from the maximum possible river flow.

\section{Chronology development}

The study plot was located in the south-western part of the recharge zone, near the top of the Kojnik hill (780 $\mathrm{m}$ a.s.l.). The sampled trees grew in a stand on a sunny slope with shallow soil depth, causing higher drought stress in trees in the growing season and a more sensitive response to climate (Poljanšek and Levanič 2012). Altogether ten $P$. nigra trees were sampled, and two cores extracted per tree. Each tree core was flushed in a Soxhlet extractor to remove resin, then dried, mounted on a wooden holder and sanded to a high polish. Cores 
were then scanned using a flat-bed scanner for tree-ring width and density measurements (Campbell et al. 2011; Sheppard et al. 1996). Images of tree-ring parameters were measured in the WinDendro programme. Measured data was imported into the PAST-4 software for cross dating and synchronisation. Quality control was done in the COFECHA programme (Grissino-Mayer 2001). After quality control, tree-ring series were processed and standardized in ARSTAN (Cook and Krusic 2005) to produce a site chronology. Individual treering parameters series (TRW and DENS) were first transformed using a power transformation to stabilise the variance (Cook and Peters 1997) and then fitted with a cubic smoothing spline with a 50\% frequency response at $67 \%$ of the series length to remove non-climatic trends due to the trees' age, size and the effects of stand dynamics (Cook and Briffa 1990). Each year's ring data was subtracted from that year's value of the fitted curve to give a dimensionless index with a mean of one. Subtraction instead of the ratio method was used, as it avoids bias caused by the lack of fit in calculating the dimensionless index (Cook and Peters 1981). Index values were then pre-whitened using an autoregressive model selected on the basis of the minimum Akaike criterion and combined across all series using biweight robust estimation of the mean to exclude the influence of outliers. A residual chronology was produced this way, containing only high-frequency variations with autocorrelation statistically removed (Cook 1985; Cook et al. 1990; Cook and Holmes 1999).

The signal strength in the residual chronologies was tested using an Expressed Population Signal - EPS (Wigley et al. 1984). EPS is calculated from data on sample depth and between-tree correlations, so the running EPS value helps define the maximum length of the potential climate reconstruction. Values of EPS below the 0.85 threshold (Briffa and Jones 1990) are considered to be too low for accurate climate reconstruction. Running window EPS statistics were calculated in ARSTAN, based on a 50-year window width and 49-year overlap, to determine portion of the chronologies usable for possible climate reconstruction (Briffa and Jones 1990; Wigley et al. 1984). Five tree-ring parameters were investigated altogether: width of complete tree-ring (TRW), early(EWW) and latewood width (LWW), and early- (MIN) and latewood density (MAX).

\section{Climate signal calculation and correlations}

The tree-ring chronologies had the last fully formed tree-ring in 2011. The first year of complete measurements of water flow in the Rižana river was in 1966 and for this reason the climate-tree growth study period was 1966-2011, altogether 46 years. Pearson correlation coefficient ( $r$ value) was calculated between individual tree-ring parameters and monthly GW data. A linear model between the residual chronology and GW was calculated using linear regression. To assess the quality of the linear model for reconstruction, the period of the available data on river discharge (1966-2011) was split into two equally long periods for calibration and verification (Kiss et al. 2011). The procedure was then repeated with the periods reversed. The reliability and prediction skill of the model was tested using reduction of error statistics (RE) (Fritts 1976), coefficient of efficiency statistics (CE) (Cook et al. 1999) and the proportion of explained variance statistic $\left(r^{2}\right)$. CE is a signal of how much better the calculated reconstruction is than a simple mean of the measured climate factor. If RE and CE coefficients are greater than zero, then the relationship has a predictive value and can be used, as far as the lengths of the chronologies permits, in reconstruction of the investigated water retention. Reconstruction is limited in length to the year in which expressed population signal (EPS), drops below 0.85 threshold $(0=<E P S=<1)$. In this study, the reconstruction is limited as follows: TRW and EWW chronology to 1937; LWW to 1940; MAX 1954; and MIN to 1967 (Poljanšek and Levanič 2012).

\section{RESULTS}

\section{Climate signal}

The highest correlation coefficient values were calculated between the periodic mean of GW and ring width parameters (TRW and LWW) (Table 1). Significant values were either calculated for an individual month, a part of the growing season, or for the period May-August. TRW, under the influence of growth factors throughout the whole season, had significant values from May till August, except for June; significant level is 0.29. EWW had a significant value for the start of the season in May, and LWW for the end of season in July. In the period where climate factors had the most influence on the timing of creation of tree-ring parameters, MIN is under the influence of May GW, and MAX under the influence of GW for June and July. 
Table 1: Correlation coefficients between residual chronologies of tree-ring parameters (TRW- tree-ring width; EWW-early-wood width; LWW-late-wood width; MIN-minimum density; MAX-maximum density) and GW data (monthly and for the period from May till August). Grey fields signify $p<0.05, n=46$.

\begin{tabular}{lccccccccccc} 
& Jan & Feb & Mar & Apr & May & Jun & Jul & Aug & Sep & Oct & May-August \\
\hline TRW & -0.08 & 0.07 & -0.03 & 0.12 & 0.32 & 0.25 & 0.46 & 0.31 & 0.02 & 0.01 & 0.61 \\
EWW & -0.07 & 0.13 & 0.03 & -0.02 & 0.29 & 0.14 & 0.22 & 0.18 & -0.08 & -0.03 & 0.37 \\
LWW & -0.07 & -0.03 & -0.08 & 0.17 & 0.24 & 0.27 & 0.61 & 0.28 & 0.09 & 0.02 & 0.64 \\
MIN & -0.11 & 0.11 & -0.01 & 0.00 & 0.38 & 0.04 & 0.02 & 0.22 & -0.05 & -0.02 & 0.30 \\
MAX & 0.02 & 0.10 & -0.28 & 0.13 & -0.18 & -0.32 & -0.49 & 0.02 & 0.09 & -0.11 & -0.42
\end{tabular}

\section{Stability of the climate signal}

The tested tree-ring parameters had significant values throughout the tested period for TRW and LWW, while others (EWW, MAX and MIN) are not significant for a period of time (Error! Reference source not found.). From recent times, back to the late 1980s, the climate signal was significant and stable in all measured tree-ring parameters. Before that, further back in the past, EWW, MAX and MIN did not have significant values.

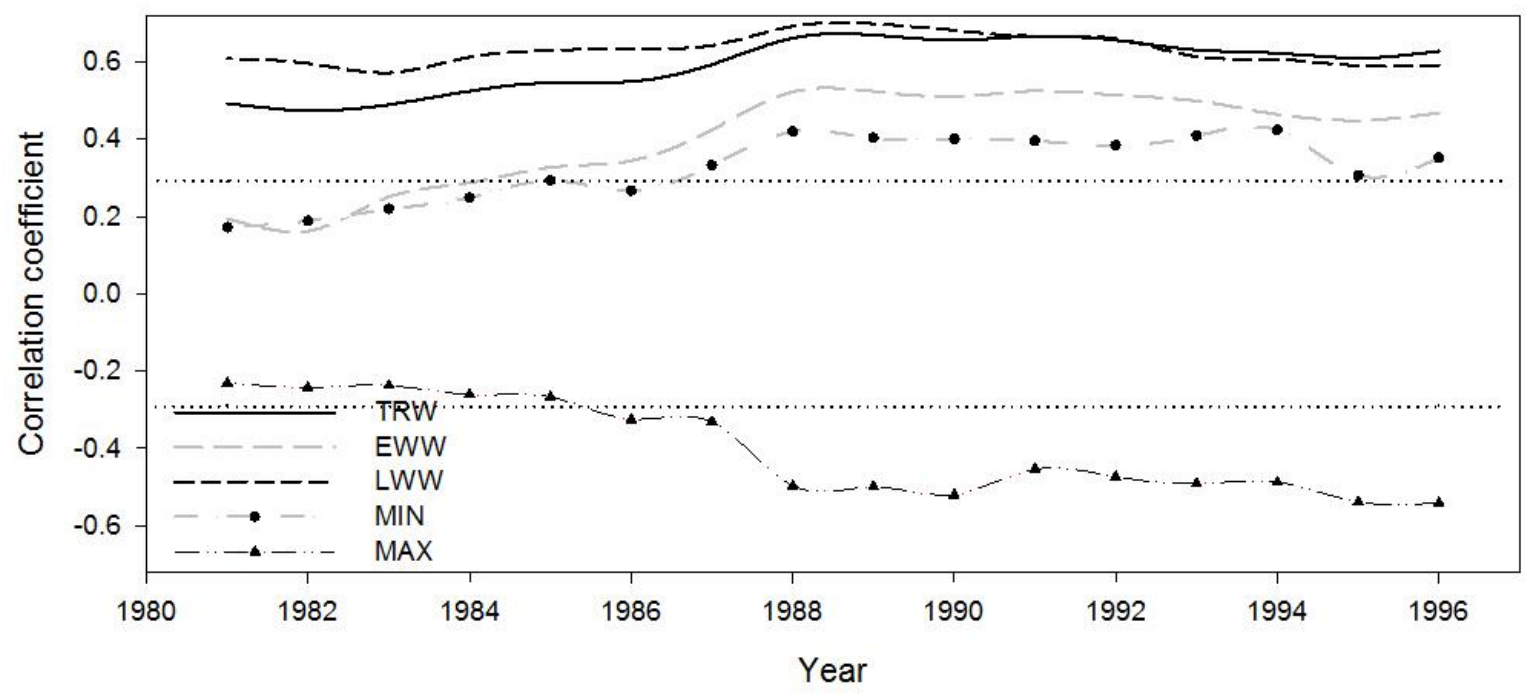

Figure 3: Stability of the climate signal, as shown using 31-year symmetrical, non-weighted running correlation between tree-ring parameters and May-August values of GW. Significance lines are set at $95 \%$ or $p<0.05$ (dotted line).

Some reduction in correlation was also seen between TRW and LWW and May-August GW values, but values remained significant throughout. Based on the significant correlations with May-August average values of GW (Table 1) and the stability of the signal from at least part of studied period (Error! Reference source not found.), a decision was made to test the strength of all tree-ring proxies for reconstruction of the amount of GW for the May-August period.

\section{Reconstruction}

CE and RE values, calculated for the verification period, were based on a comparison between a measured climate factor and its reconstruction, calculated from a linear model for calibration period. The periods for verification and calibration are represented as two, equally long halves $(n=23)$ of the available time period for 
climate-tree growth analysis, in our case 1966-1988 and 1989-2011. Reconstruction, based on the linear model between GW and TRW data for a calibration period of 1989-2011 (backward), was tested against measured GW data for the 1966-1988 period, and was shown to be weaker than with the periods reversed (i.e. forward). There was less difference between the two periods for LWW (Table 2). Negative values of RE and/or CE were calculated in the case of the density measurements and EWW, and so reconstruction using these proxies is therefore unsuitable. Only TRW and LWW have sufficient predictive power for the reconstruction of river flow.

Table 2: Measures of the strength of the linear model for the reconstruction of individual tree-ring parameters. Bold numbers signify adequate values for reconstruction.

\begin{tabular}{c|lcccc} 
& \multicolumn{5}{|c}{ calibration } \\
parameter & period & $r^{2}$ & $r^{2}$ & $\mathrm{RE}$ & $\mathrm{CE}$ \\
\hline \multirow{2}{*}{ TRW } & Backward: 1989-2011 & 0.58 & 0.20 & $\mathbf{0 . 1 7}$ & $\mathbf{0 . 1 1}$ \\
& Forward: 1966-1988 & 0.20 & 0.58 & $\mathbf{0 . 5 2}$ & $\mathbf{0 . 4 8}$ \\
& $1966-2011$ & 0.37 & & & \\
\hline \multirow{2}{*}{ EWW } & $1989-2011$ & 0.38 & 0.00 & -0.12 & -0.21 \\
& $1966-1988$ & 0.00 & 0.38 & 0.09 & 0.02 \\
& $1966-2011$ & 0.14 & & & \\
\hline \multirow{2}{*}{ LWW } & $1989-2011$ & 0.46 & 0.40 & $\mathbf{0 . 3 4}$ & $\mathbf{0 . 2 9}$ \\
& $1966-1988$ & 0.40 & 0.46 & $\mathbf{0 . 3 8}$ & $\mathbf{0 . 3 3}$ \\
& $1966-2011$ & 0.41 & & & \\
\hline \multirow{2}{*}{ MAX } & $1989-2011$ & 0.36 & 0.02 & 0.01 & -0.06 \\
& $1966-1988$ & 0.02 & 0.36 & 0.26 & 0.20 \\
& $1966-2011$ & 0.18 & & & -0.28 \\
\hline \multirow{2}{*}{ MIN } & $1989-2011$ & 0.25 & 0.04 & -0.19 & 0.02 \\
& $1966-1988$ & 0.04 & 0.25 & 0.09 &
\end{tabular}

\section{DISCUSSION}

\section{Climate signal}

Trees respond only to retained soil moisture, and excess water drains away from trees, especially on a soil with low water retention capability or on shallow soil, as in our case (Error! Reference source not found.). In this research, precipitation and river flow data were combined to investigate the response of trees to the amount of water remaining in the forest after precipitation events. This way, GW was calculated with values representing the water used in various processes from photosynthesis to evapotranspiration. GW, as the difference between precipitation and river flow, was highest in spring and summer months (Error! Reference source not found.), while the lowest values of water retention were calculated for the winter months (DecMar), that is, in the period of no growth activity. When growth starts, trees use water and occasionally, as in July and August, there was even higher potential evapotranspiration than precipitation (Ogrin 2005). Relatively high values of GW were also calculated for the autumn, but these values can be assigned to physical processes in the soil, as it needs to regain its moisture after the summer deficit.

To test if using combined precipitation and river flow can improve the climate signal, a decision was made to use tree-ring parameters for $P$. nigra from a previous investigation (Poljanšek and Levanič 2012). In previous research, the strongest connection was found using precipitation as an individual climate factor, for the period May-August and TRW; $r=0.44$. Using calculated GW, the strength of the climate signal, connected to soil moisture, increased; $r=0.61$ (Table 1). Also, the signal strength of MAX, with a precipitation signal for the MayAugust period ( $r=-0.10)$, improved with the addition of May-August GW to $r=-0.42$ (Table 1). Confidence in the influence of GW on tree-ring parameters was also increased by the significance of correlation coefficients from particular months in which certain events take place. Before May, no significant correlations were calculated for any of the tree-ring parameters. The start of the season is expected to be in late March or early April whilst 
wood formation in a more southerly location than this study, in the western part of Bosnia and Herzegovina $(\mathrm{BiH})$, was discovered to begin in the middle of March (unpublished data).

In the first weeks after the start of wood formation, trees usually function and grow based on nutrition from the previous growing season, particularly in areas with harsh climatic conditions (Babst et al. 2013). In our case, current climate conditions started to affect MIN and EWW, and TRW in May. Based on results from BiH (unpublished data), the transition from earlywood formation to latewood also starts in May. June would be assumed to have greater influence on all proxies, but in this month, there was an above average amount of summer precipitation (Error! Reference source not found.) and for some weeks, trees grew without moisture stress. Regarding the whole growing season, GW for the May-August period was important for TRW. This was a result of the positive influence of GW on EWW in the first part of the season and on LWW in the second. The same is true for the influence of GW on tree-ring density, with May values of GW important for MIN, and to some extent GW influencing MAX as well. An explanation for why there was no significant influence of August GW on MAX could be that the densest wood was formed in the June-July period (Table 1). If the transition from earlywood to latewood was in May, then we would assume that the largest number of latewood cells were created in June, but with July being the month in which drought stress, or in our case the amount of GW, would define how much cells will grow and therefore how dense the latewood will be. After the peak of drought stress in July, the last wood cells produced and matured in August could simply be less dense. However, investigation of wood formation from this particular area would improve knowledge on this matter considerably.

\section{Stability of the climate signal}

Insight into the stability of the climate signal, to investigate how climate factors influenced tree-ring parameters through time, is important in the light of climate change. In our case, a stable and strong influence of GW on LWW and TRW was observed, but in all the investigated parameters, a decrease in GW signal strength around the 1980s was noticed (Error! Reference source not found.). The reason for this change in climate signal could be in the anomalously cyclonic circulation and enhanced cloudiness, and therefore less drought stress in soil moisture values, as in the case of sunny weather, trees would encounter more drought stress. This phenomenon presumably affected the sunshine signal in TRW from the Balkan Peninsula (Poljanšek et al. 2013). More detailed investigation of the climate data could shine a light on this matter, but data on sunshine hours or air pressure from this region are absent, and there is also a strong influence from the hills and valleys on precipitation (Janža 2010). Regardless, the tree-ring parameters TRW and LWW have the strongest correlation coefficients, and also the most stable climate signals for the May-August values of GW. LWW has an even stronger signal in the past than TRW. This is also seen in the reconstruction strength (Table 2), as well as in the linear regression (Error! Reference source not found.). There is one value that stands out in the comparison of the TRW and LWW regression lines (Error! Reference source not found.): the dot for LWW for 2010, in the upper part of the figure, is possibly the result of the so-called end effect in residual chronology calculation, when the mathematical division of the value for the measured tree-ring parameter with a very small value for the fitted standardization curve, results in an outlier value. Overreaction in 2010 is also seen in the calculated reconstruction based on LWW data, with the higher value, when compared to the reconstruction, based on TRW (Error! Reference source not found.). 


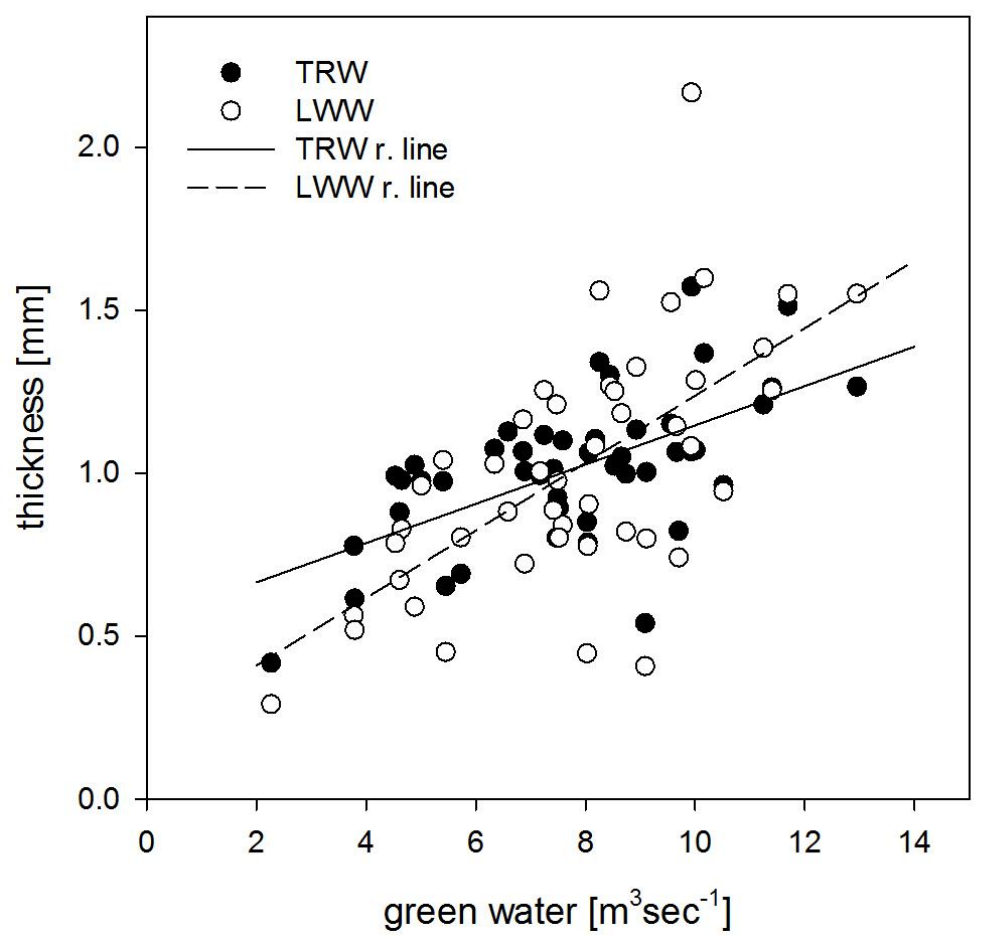

Figure 4: Scatter plot and linear regression for the whole period (1966-2011) between GW and tree-ring proxies (TRW (black dots) and LWW (white dots)).

\section{Reconstruction}

Based on high and significant values of the correlation between tree-ring parameters and climate data on GW, GW can be reconstructed back to 1937 using TRW, and using LWW back to 1940 (Error! Reference source not found.). RE and CE coefficients showed LWW as the most appropriate for reconstruction of GW. Unfortunately, the chronologies used in previous research were developed to investigate the climate signal in tree-ring widths and tree-ring densities, and not to construct the longest possible chronology. For this reason, records on moisture stress were only extended for 25 years further back into the past using TRW, and 22 years further back using LWW. Sampling older trees than those used in this investigation would increase the length of the reconstruction considerably.

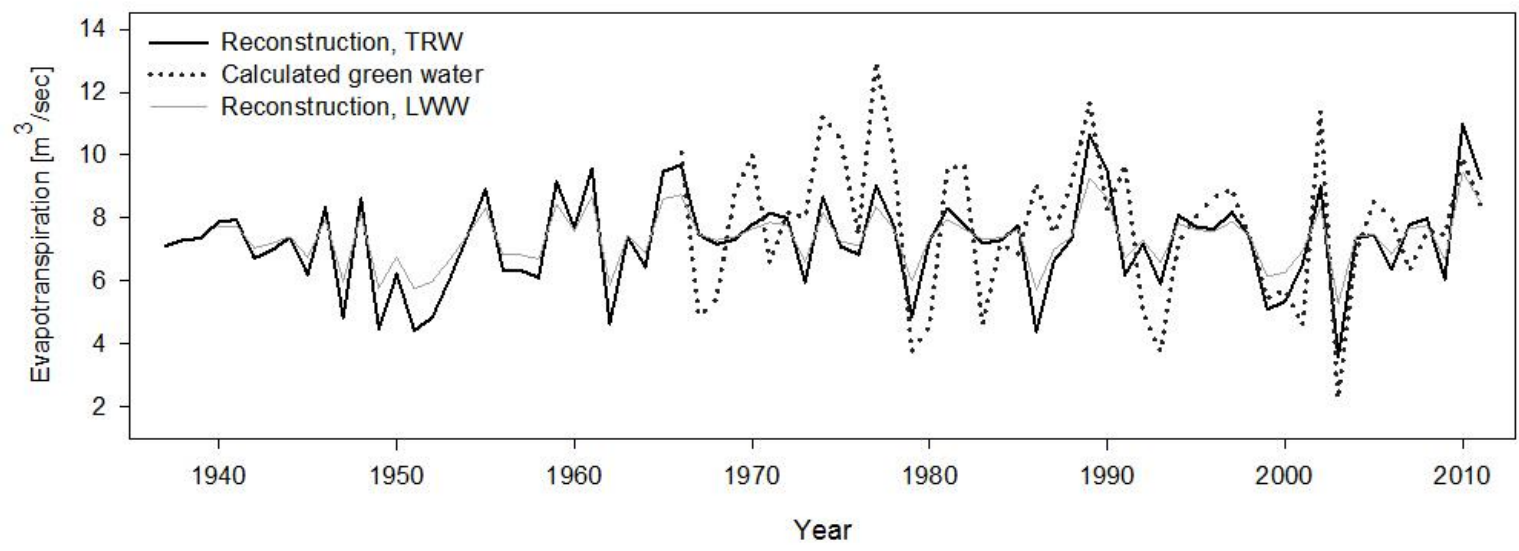


Figure 5: Comparison of calculated values of GW (dotted line) and two possible reconstructions of May-August GW, based on TRW measurements (solid black line) and LWW (grey line).

A decrease in the GW signal strength in the period around the 1980s was also observed in the reconstruction. In this period, TRW reconstruction showed a better result than LWW, regardless of better results in the correlation coefficients or RE/CE values. Despite some differences between the two reconstructions and measured GW, the values have the same direction, showing parallel increases and decreases, for example, in 2003, a year of extreme summer drought which caused growth reductions also seen elsewhere (Ciais et al. 2005). However, in 1986 the measured GW showed an increase in value compared to the previous season, but both values were calculated as a decrease. We point out that not all extreme years can be connected to climate factors.

Forest fires, in particular fast crown fires, for example, can reduce the number of needles on a tree, resulting in a sudden growth decline, but not necessarily mortality. Such events influence growth over many years (Poljanšek et al. 2014), while drought is usually season specific and visible as a narrow ring in the year of drought, or at most in the next tree-ring. Of course, two events can happen synchronically, especially as fire is prone to follow drought.

\section{CONCLUSIONS}

Using otherwise complex karst underground system as a complete and simplified watershed in a simple calculation of the GW, representing the difference between the precipitation and river flow from the entire Rižana water catchment, and correlation coefficient calculation between GW and tree-ring parameters, showed that $P$. nigra trees were good recorders of ecosystem water use. The signal is significant and stable in time, which enabled reconstruction of GW to a pre-instrumental period. Additional sampling of trees, growing in the Rižana river watershed, and older than presented in this study, could prolong reconstructed values considerably. More precise calculation of water use, via data on soil characteristics, could even improve the already high correlations. These useful results can be used in drought investigations and studies of adaptations of agriculture/forestry in the coastal area of Slovenia to climate change. Similar studies could also be tested elsewhere, for example in the karstic regions of the Dinaric Mountains on the Balkan Peninsula.

\section{ACKNOWLEDGMENTS}

The authors wish to thank Ed Eaton from Forest Research (UK) for language check and Mladen Prebevšek, Slovenian Forestry Service for his field cooperation. A special thanks also to the Slovenian Science Foundation, as well as the World Federation of Scientists for supporting the work of Simon Poljanšek. This research was financially supported by the Slovenian Research Agency project grant J4-5519 "Paleoclimate data enhances drought prediction in the W Balkan region « and the Program and Research group P4-0107 "Forest ecology, biology and technology" of the Slovenian Forestry Institute funded by the Slovenian Research Agency.

\section{REFERENCES}

Babst F et al. (2013) Site-and species-specific responses of forest growth to climate across the European continent Global Ecology and Biogeography 22:706-717

Briffa KR, Jones PD (1990) Basic chronology statistics and assessment. In: Cook ER, Kairiukstis LA (eds) Methods of dendrochronology: applications in the environmental sciences. Kluwer academic publishers, Dordrecht, Boston, London, pp 137-152

Campbell R, McCarroll D, Robertson I, Loader NJ, Grudd H, Gunnarson B (2011) Blue Intensity In Pinus sy/vestris Tree Rings: A Manual for A New Palaeoclimate Proxy Tree-Ring Research 67:127-134 doi:10.3959/2010-13.1

Chang M (2006) Forest hydrology: an introduction to water and forests. CRC press, 
Ciais P et al. (2005) Europe-wide reduction in primary productivity caused by the heat and drought in 2003 Nature

doi:http://www.nature.com/nature/journal/v437/n7058/suppinfo/nature03972_S1.html

Cook E, Krusic PJ (2005) ARSTAN v. 41d: A tree-ring standardization program based on detrending and autoregressive time series modeling, with interactive graphics. Tree-Ring Laboratory, Lamont-Doherty Earth Observatory of Columbia University, Palisades, New York, USA,

Cook ER (1985) Time series analysis approach to tree ring standardization. Dissertation, University of Arizona

Cook ER, Briffa K, Shiyatov S, Mazepa V (1990) Tree-Ring Standardization and Growth Trend Estimation. In: Cook ER, Kairiukstis LA (eds) Methods of dendrochronology: applications in the environmental sciences. Kluwer academic publishers, Dordrecht, Boston, London, pp 104-162

Cook ER, Briffa KR (1990) A comparison of some tree-ring standardization methods. In: Cook ER, Kairiukstis LA (eds) Methods of Dendrochronology: Applications in the Environmental Sciences. Kluwer Academic Publishers, Dordrecht, Boston, London, pp 153-162

Cook ER, Holmes RL (1999) Program ARSTAN - chronology development with statistical analysis (users manual for program ARSTAN). Laboratory of Tree-Ring Research, University of Arizona, Tucson

Cook ER, Meko DM, Stahle DW, Cleaveland MK (1999) Drought Reconstructions for the Continental United States Journal of Climate 12:1145-1162 doi:10.1175/1520-0442(1999)012<1145:drftcu>2.0.co;2

Cook ER, Peters K (1981) The smoothing spline: a new approach to standardizing forest interior tree- ring width series for dendroclimatic studies Tree-Ring Bulletin 41:45-54

Cook ER, Peters K (1997) Calculating unbiased tree-ring indices for the study of climatic and environmental change The Holocene 7:361-370

Dawson TE (1996) Determining water use by trees and forests from isotopic, energy balance and transpiration analyses: the roles of tree size and hydraulic lift Tree Physiology 16:263-272

Ernst C, Gullick R, Nixon K (2004) Conserving forests to protect water Am Water W Assoc 30:1-7

Falkenmark M, Rockström J (2006) The new blue and green water paradigm: Breaking new ground for water resources planning and management Journal of water resources planning and management 132:129132

Fritts HC (1976) Tree rings and climate. Academic Press, London, New York, San Francisco

Gaelle T, Mohammed B (2011) Water and forest resources and people in the mediterranean: the current situation Water for forests and people in the mediterranean region: a challenging balance European Forest Institute, Joensuu:22-31

Grissino-Mayer HD (2001) Evaluating crossdating accuracy: A manual and tutorial for the computer program COFECHA. Tree-Ring Research 57:205-221

Janža M (2010) Hydrological modeling in the karst area, Rižana spring catchment, Slovenia Environ Earth Sci 61:909-920 doi:10.1007/s12665-009-0406-9

Jurko M (2009) Statistična analiza trendov značilnih pretokov slovenskih rek. Univerza v Ljubljani

Kiss A, Wilson R, Bariska I (2011) An experimental 392-year documentary-based multi-proxy (vine and grain) reconstruction of May-July temperatures for Kőszeg, West-Hungary International Journal of Biometeorology 55:595-611 doi:10.1007/s00484-010-0367-4

Kranjc A (2009) History of Deforestation and Reforestation in the Dinaric Karst Geographical Research 47:15-23 doi:10.1111/j.1745-5871.2008.00552.x

Krivic P, Bricelj M, Trišič N, Zupan M (1987) Water tracing experiment in the Rižana spring ground water basin (in Slovene) Acta carsologica 16:83-104

Muys B, Ceci P, Hofer T, Veith C (2011) Towards integrated ecological, socio-economic and hydrological management Water for forest and people in the Mediterranean Region-a challenging balance EFI Series What Science can tell us 1:105-113

Nisbet T (2005) Water use by trees. Forestry Commission, Alice Holt Lodge, Farnham, UK

Ogrin D (2005) Tree rings and climate in submediterranean Slovenia. In: Heinrich I, Gärtner H, Monbaron M, G S (eds) TRACE - Tree Rings in Archaeology, Climatology and Ecology, Fribourg, Switzerland, 2005. pp 7783

Oishi AC, Oren R, Novick KA, Palmroth S, Katul GG (2010) Interannual Invariability of Forest Evapotranspiration and Its Consequence to Water Flow Downstream Ecosystems 13:421-436 doi:10.1007/s10021-0109328-3

Poljanšek S, Ceglar A, Levanič T (2013) Long-term summer sunshine/moisture stress reconstruction from treering widths from Bosnia and Herzegovina Climate of the Past 9:27-40 doi:10.5194/cp-9-27-2013

Poljanšek S, Levanič T (2012) Multiple tree-ring parameters from Pinus nigra (Arnold) and their climate signal Zbornik gozdarstva in lesarstva:15-25 
Poljanšek S, Levanič T, Ballian D, Jalkanen R (2014) Tree growth and needle dynamics of P. nigra and P. sylvestris and their response to climate and fire disturbances Trees:1-12 doi:10.1007/s00468-0141146-3

Saito L, Biondi F, Devkota R, Vittori J, Salas JD (2015) A water balance approach for reconstructing streamflow using tree-ring proxy records Journal of Hydrology 529:535-547 doi:10.1016/j.jhydrol.2014.11.022

Sheppard PR, Graumlich L, Conkey LE (1996) Reflected-light image analysis of conifer tree rings for reconstructing climate The Holocene 6:62-68 doi:10.1177/095968369600600107

Spraggs G, Peaver L, Jones P, Ede P (2015) Re-construction of historic drought in the Anglian Region (UK) over the period 1798-2010 and the implications for water resources and drought management Journal of Hydrology 526:231-252 doi:10.1016/j.jhydrol.2015.01.015

Wigley TML, Briffa KR, Jones PD (1984) On the average value of correlated time series, with applications in dendroclimatology and hydrometeorology Journal of Climate and Applied Meteorology 23:201-213 